University of Nebraska - Lincoln

DigitalCommons@University of Nebraska - Lincoln

\title{
Protein and Lysine Contents of Endosperm and Bran of the Parents and Progenies of Crosses of Common Wheat
}

Kenneth P. Vogel

University of Nebraska-Lincoln, kvogel1@unl.edu

V. A. Johnson

SEA - USDA

P. J. Mattern

SEA - USDA

Follow this and additional works at: https://digitalcommons.unl.edu/usdaarsfacpub

Vogel, Kenneth P.; Johnson, V. A.; and Mattern, P. J., "Protein and Lysine Contents of Endosperm and Bran of the Parents and Progenies of Crosses of Common Wheat" (1978). Publications from USDA-ARS / UNL Faculty. 1874.

https://digitalcommons.unl.edu/usdaarsfacpub/1874

This Article is brought to you for free and open access by the U.S. Department of Agriculture: Agricultural Research Service, Lincoln, Nebraska at DigitalCommons@University of Nebraska - Lincoln. It has been accepted for inclusion in Publications from USDA-ARS / UNL Faculty by an authorized administrator of DigitalCommons@University of Nebraska - Lincoln. 


\title{
Protein and Lysine Contents of Endosperm and Bran of the Parents and Progenies of Crosses of Common Wheat ${ }^{1}$
}

\author{
K. P. Vogel, V. A. Johnson, and P. J. Mattern ${ }^{2}$
}

\begin{abstract}
Grain samples from parent and progeny rows of the common wheat (Triticum aestivum L.) crosses, 'Nap Hal'/ 'Atlas 66' and Nap $\mathrm{Hal} /$ 'Super $X$ ', were fractionated into their starchy endosperm and bran components to determine the within-kernel site of their variation in protein and lysine concentration. Nap Hal and Atlas 66 are highprotein wheats. Nap Hal also has elevated grain lysine content. Super $\mathbf{X}$ has average protein and lysine content. Transgressive segregation existed both for high and low endosperm protein concentration among the $F_{5}$ progeny rows of Nap Hal/Atlas 66. Low-protein progeny rows had endosperm protein percentages that were 3 to 5 percentage points lower than the parental mean $(19.5 \%)$. High-protein progeny lines were 2 to 4 percentage points higher than the parental mean. Nap Hal and some of the progeny rows were 5 percentage points higher in bran protein content than Atlas 66. Endosperm and bran protein percentages of Nap Hal/Super $X \mathrm{~F}_{4}$ progeny were within the parental range. Some progeny rows had endosperm and bran protein concentrations equal to those of Nap Hal. Variation among the progeny rows for endosperm and bran lysine (\% of protein) concentrations was within the range of variability of the replicated parental rows. Variation for grain protein content among the progeny rows of both crosses was due to variation for both endosperm and bran protein content. Variation for grain lysine ( $\%$ of sample) among the Nap Hal/Atlas 66 progeny rows was due primarily to variation in endosperm and bran protein content with endosperm and bran lysine (\% of protein) being of lesser importance.
\end{abstract}

Additional index words: Triticum aestivum L., Transgressive segregation, Kernel fractionation, Protein quality.

$\mathbf{M}$

OST of the breeding and genetic research on the protein and lysine content of wheat (Triticum aestivum L.) has been conducted on whole grain samples, However, variation among wheats for whole grain protein and lysine content can be due to variation in endosperm and bran protein and lysine concentrations as well as to variation in the proportion of seed that is bran (12). In this paper, the term endosperm refers to the starchy endosperm and the term bran refers to all other kernel components including the aleurone layer. Lysine can be expressed either as a percentage of sample or as a percentage of protein. Lysine (percent of protein) is a measure of protein quality while lysine (percent of sample) is a function of both the protein and lysine (percent of protein) concentrations of a sample. Unless otherwise specified, the term lysine will refer to lysine (percent of protein).

Whole grain samples have been used in most wheat protein and lysine genetic studies because of the difficulty of uniformly and cleanly separating endosperm and bran. Uniform separation of endosperm and bran is required for protein and lysine analyses because the bran is higher in protein and lysine concentration than the endosperm $(12,13)$ and because there is a protein gradient within the endosperm with the outer part of the endosperm being higher in protein concentration than the interior of the kernel $(2,7)$.

A modified milling procedure has been developed that can be used to cleanly and uniformly separate endosperm and bran for protein and lysine analyses (13). We used this method on 129 wheats from the USDA World Wheat Collection and on four replications of six clieck cultivars grown in the same nursery at Yuma, Arizona, in 1973 (12). Significant differences were detected among the wheats for grain, endosperm, and bran protein and lysine concentration. ' $\mathrm{Nap} \mathrm{Hal}$ ' and 'Atlas 66' were included as high-protein checks in this study. Atlas 66 has high grain protein content because of its high endosperm protein content. The high grain protein content of Nap $\mathrm{Hal}$ is due to both

\footnotetext{
${ }^{1}$ Contribution of the Dep. of Agronomy, Univ. of NebraskaLincoln, and SEA.USDA, Lincoln, NE 68583. Part of a dissertation submitted by the senior author to the Graduate College of the Univ. of Nebraska-Lincoln in partial fulfillment of the requirements for the Ph.D. degree. The research was supported in part by funds from USAID, Washington, D.C. Contract Nos. AID/csd-1208 and AID/ta-c-1093. Published as Paper 4044, Journal Series. Nebraska Agric. Exp. Stn. Received 5 Nov. 1977.

${ }^{2}$ Research agronomists, SEA.USDA, and professor (Cereal Quality), Univ, of Nebraska-Lincoln, Lincoln, NE 68583, respectively.
} 
Table 1. Grain, endosperm, and bran protein and lysine percentages and 100-kernel weights for parent, check, and progeny rows of Nap Hal/Atlas 66 .

\begin{tabular}{|c|c|c|c|c|c|c|c|}
\hline & \multicolumn{2}{|c|}{ Grain } & \multicolumn{2}{|c|}{ Endosperm } & \multicolumn{2}{|c|}{ Bran } & \multirow{2}{*}{$\begin{array}{l}100- \\
\text { kerne } \\
\text { wt. }\end{array}$} \\
\hline & $\mathrm{P} \dagger$ & LP & $\mathbf{P}$ & LP & $\mathbf{P}$ & LP & \\
\hline \multirow{4}{*}{$\begin{array}{l}\text { Means: } \\
\text { Centurk } \\
\text { Atlas } 66 \\
\text { Nap Hal } \\
\text { Nap Hal/Atlas } 66 \\
\text { progeny }\end{array}$} & & & & & & & g \\
\hline & $\begin{array}{l}15.5 \\
19.4\end{array}$ & $\begin{array}{l}3.0 \\
2.8\end{array}$ & $\begin{array}{l}15.0 \\
19.3\end{array}$ & $\begin{array}{l}2.5 \\
2.5\end{array}$ & $\begin{array}{l}19.6 \\
19.8\end{array}$ & $\begin{array}{l}4.5 \\
4.4\end{array}$ & $\begin{array}{l}3.66 \\
3.63\end{array}$ \\
\hline & 19.6 & 3.1 & 19.0 & 2.5 & 24.5 & 4.6 & 2.66 \\
\hline & 20.6 & 2.9 & 20.1 & 2.5 & 23.0 & 4.4 & 3.15 \\
\hline \multirow{3}{*}{$\begin{array}{l}\text { C.V. }(\%) \\
\text { L.S.D. (0.05) } \\
\text { Progeny standard } \\
\text { deviation (s) }\end{array}$} & 2.7 & 1.5 & 2.5 & 2.3 & 2.4 & 7.2 & 3.32 \\
\hline & & & 0.9 & & 1.0 & N.S. & 0.22 \\
\hline & 1.8 & 0.1 & 2.0 & 0.1 & 1.6 & 0.2 & 0.31 \\
\hline
\end{tabular}

$\dagger \mathbf{P}=$ percent protein; $\mathbf{L P}=$ lysine (percent of protein). L.S.D. values listed only when the ' $F$ ' ratio from the analyses of variance was significant at the 0.05 level. Coefficients of variation and L.S.D. values were obtained from the analysis of variance of the parent and check rows.

its high endosperm protein content and its very high bran protein content. Nap Hal also exhibits high grain lysine content because of its high bran protein content and because of the high lysine content of its endosperm. Bran proteins contain $50 \%$ more lysine than endosperm proteins (12).

Grain protein and lysine concentrations of the parents and $\mathrm{F}_{2}$ progeny bulks in the $\mathrm{F}_{3}$ and $\mathrm{F}_{4}$ generations of the cross $\mathrm{Nap} \mathrm{Hal/Atlas} 66$ have been reported (3, 4). Transgressive segregation was reported for both low and high grain protein. Nap Hal/Atlas 66 progenies varied for grain lysine concentration but exhibited no transgressive segregation $(3,4)$. The purpose of this study was to determine the within-kernel sites for protein and lysine variation among progenies of the crosses Nap Hal/Atlas 66 and Nap Hal/'Super $\mathrm{X}^{\prime}$.

\section{MATERIALS AND METHODS}

Nap Hal, PI 176217 , is a soft red spring wheat from an old Indian cultivar that was first identified as a high-protein wheat by Watson et al. (14) and as a high-lysine line by Johnson et al. (5). Atlas 66, CI 12561, is a high-protein soft red winter wheat that has been used extensively in breeding programs as a high-protein parent (8). Super $X$ is a short-statured red spring wheat with good agronomic traits but with neither high protein nor high lysine.

Heads were selected from Nap Hal/Atlas $66 F_{2}$ progeny bulks grown in the $F_{4}$ and from Nap Hal/Super $X F_{2}$ progeny bulks grown in the $F_{3}$ at Yuma, Arizona, in 1972. Seeds from the selected heads were planted in an irrigated nursery at Yuma in the 1972.73 growing season in single $1.37 \mathrm{~m}$ head row plots spaced $51 \mathrm{~cm}$ apart. Seeds from a single head were used to plant a head row. Head or progeny rows from a progeny bulk were planted in the same set within a block. Parents and the check cultivar 'Centurk' were planted at the ends of each set of progeny rows within a nursery block. The nursery was fertilized with $112.1 \mathrm{~kg} / \mathrm{ha}$ of $\mathrm{N}$.

Head rows were selected for harvest on the basis of their desirable agronomic appearance and on the protein and lysine concentration of their parent $F_{2}$ progeny bulk row in the previous year. Whole grain protein and lysine contents were determined on 136 and 94 headrows of Nap Hal/Atlas 66 and Nap Hal/Super X, respectively.

Wheats that represented the range of grain protein and lysine values among the head rows from each cross were selected for endosperm and bran protein and lysine analyses. Ninetyfour rows were selected from the Nap Hal/Atlas 66 population, including three rows each of the parent and check cultivars. Eighteen rows were selected from the Nap Hal/Super X popula. tion including two rows each of the parent and check cultivars.
Table 2. Grain, endosperm, and bran protein and lysine percentages and 100-kernel weights for parent, check, and progeny rows of Nap Hal/Super X.

\begin{tabular}{|c|c|c|c|c|c|c|c|}
\hline & \multicolumn{2}{|c|}{ Grain } & \multicolumn{2}{|c|}{ Endosperm } & \multicolumn{2}{|c|}{ Bran } & \multirow{2}{*}{$\begin{array}{c}100- \\
\text { kerne } \\
\text { wt. }\end{array}$} \\
\hline & $\mathbf{P} \dagger$ & $\mathbf{L P}$ & $\mathbf{P}$ & LP & $\mathbf{P}$ & LP & \\
\hline Means: & & & & & & & $\mathbf{g}$ \\
\hline & $\begin{array}{l}13.2 \\
17.0\end{array}$ & $\begin{array}{l}3.2 \\
3.2\end{array}$ & $\begin{array}{l}12.7 \\
16.3\end{array}$ & $\begin{array}{l}2.8 \\
2.8\end{array}$ & $\begin{array}{l}17.0 \\
22.4\end{array}$ & $\begin{array}{l}4.7 \\
4.7\end{array}$ & $\begin{array}{l}3.65 \\
2.49\end{array}$ \\
\hline $\begin{array}{l}\text { Super X } \\
\text { Nap Hal/Super X }\end{array}$ & 12.8 & 3.0 & 12.6 & 2.7 & 16.2 & 4.4 & 3.92 \\
\hline progeny & 15.6 & 3.2 & 14.9 & 2.7 & 20.7 & 4.7 & 3.02 \\
\hline \multirow{2}{*}{$\begin{array}{l}\text { C.V. }(\%) \\
\text { L.S.D. (0.05) } \\
\text { Progeny standard } \\
\text { deviation (s) }\end{array}$} & $\begin{array}{l}1.6 \\
0.8\end{array}$ & $\begin{array}{r}2.5 \\
\text { N.S. }\end{array}$ & $\begin{array}{l}2.7 \\
1.2\end{array}$ & $\begin{array}{l}3.7 \\
\text { N.S. }\end{array}$ & $\begin{array}{l}2.2 \\
1.3\end{array}$ & $\begin{array}{r}2.7 \\
\text { N.S. }\end{array}$ & $\begin{array}{l}2.77 \\
0.30\end{array}$ \\
\hline & 1.0 & 0.2 & 1.0 & 0.1 & 1.5 & 0.2 & 0.49 \\
\hline
\end{tabular}

$\dagger \mathbf{P}=$ percent protein; $\mathbf{L P}=$ lysine (percent of protein). L.S.D. values listed only when the ' $F$ ' ratio from the analyses of variance was significant at the 0.05 level. Coefficients of variation and L.S.D. values were obtained from the analysis of variance of the parent and check rows.

Table 3. Correlation coefficients for whole grain, endosperm, and bran protein and lysine percentages for the Nap Hal/Atlas 66 progeny and for the Nap Hal/Super $X$ progeny.

\begin{tabular}{|c|c|c|c|c|c|c|}
\hline & \multirow{2}{*}{$\frac{\text { Grain }}{\mathrm{LP} \dagger}$} & \multicolumn{2}{|c|}{ Endosperm } & \multicolumn{2}{|c|}{ Bran } & \multirow{2}{*}{$\begin{array}{c}100- \\
\text { kernel } \\
\text { wt. }\end{array}$} \\
\hline & & $\mathbf{P}$ & LP & $\mathbf{P}$ & LP & \\
\hline \multicolumn{7}{|c|}{ Nap Hal/Atlas 66} \\
\hline \multicolumn{7}{|l|}{ Grain } \\
\hline $\begin{array}{l}\% \text { protein } \\
\text { Lysine (\% of } \\
\text { protein) }\end{array}$ & $-0.60 * *$ & $\begin{array}{r}0.98^{* *} \\
-0.61^{* *}\end{array}$ & $\begin{array}{r}-0.50^{* *} \\
0.57^{* *}\end{array}$ & $\begin{array}{c}0.67^{* *} \\
-0.19\end{array}$ & $\begin{array}{r}-0.45^{* *} \\
0.43^{* *}\end{array}$ & $\begin{array}{r}0.04 \\
-0.07\end{array}$ \\
\hline \multicolumn{7}{|l|}{ Endosperm } \\
\hline $\begin{array}{l}\% \text { protein } \\
\text { Lysine (\% of } \\
\text { protein) }\end{array}$ & & ap Hal/S & $-0.51^{* *}$ & $\begin{array}{c}0.58^{* *} \\
-0.35^{* *}\end{array}$ & $\begin{array}{c}-0.44^{* *} \\
0.08\end{array}$ & $\begin{array}{r}0.09 \\
-0.05\end{array}$ \\
\hline Grain & & & & & & \\
\hline $\begin{array}{l}\% \text { protein } \\
\text { Lysine (\% of } \\
\text { protein) }\end{array}$ & $-0.70^{* *}$ & $\begin{array}{l}0.96^{* *} \\
-0.58^{*}\end{array}$ & -0.01 & $\begin{array}{r}0.49 \\
-0.31\end{array}$ & $\begin{array}{c}-0.68^{*} \\
0.69\end{array}$ & $\begin{array}{r}-0.52 \\
0.12\end{array}$ \\
\hline Endosperm & & & & & & \\
\hline $\begin{array}{l}\text { \% protein } \\
\text { Lysine (\% of } \\
\text { protein) }\end{array}$ & & & 0.55 & $\begin{array}{l}0.37 \\
0.27\end{array}$ & $\begin{array}{l}-0.67^{*} \\
-0.09\end{array}$ & $\begin{array}{l}-0.65^{*} \\
-0.52\end{array}$ \\
\hline
\end{tabular}

*,** Indicates significance at the 0.05 and 0.01 levels of probability re spectively. $\quad+$ Abbreviations: $P=$ percent protein, $L P=$ lysine (\% of protein). $\mathbf{N}=85$ and 12 for the Nap Hal/Atlas 66 and the Nap Hal/ Super $\mathrm{X}$ progenies, respectively.

The modified milling procedure described by Vogel et al. (13) was used to uniformly separate bran and starchy endosperm. After milling, the starchy endosperm adhering to the mill bran was removed by a washing procedure, dried, and added to the mill flour to reconstitute the starchy endosperm. A $20 \mathrm{~g}$ sample of grain from each row was separated into endosperm and bran for protein and lysine analyses.

Macro-Kjeldahl procedure AACC Method 46-12 (1) was used to determine $\mathbf{N}$ content of the sample. Protein content was calculated as percent $N \times 5.7$. Ion exchange chromatography was used to determine lysine content of the sample (6). Results of all protein and lysine analyses were expressed on a dry weight basis.

The progeny head rows were not replicated. The parent and chcek cultivars were analyzed using analyses of variance procedures assuming a completely randomized design to obtain an estimate of within-nursery environmental variation. Standard partial regression coefficients, which provide an indication of the relative importance of the independent variables, were calculated for the Nap Hal/Atlas 66 progeny using multiple regression analyses (9). The Nap Hal/Super $\mathrm{X}$ population was too small for multiple regression analyses. 
Table 4. Intercepts, partial regression coefficients, and standardized partial regression coefficients for grain protein and lysine concentrations from the multiple regression analyses of 85 Nap Hal/Atlas 66 progeny rows.

\begin{tabular}{|c|c|c|c|c|c|c|}
\hline $\begin{array}{l}\text { Dependent } \\
\text { variables }\end{array}$ & $\begin{array}{c}\text { Independent } \\
\text { variables }\end{array}$ & $\begin{array}{l}\text { Intercept } \\
\text { for model }\end{array}$ & $\begin{array}{l}\text { Regression } \\
\text { coeff. }\end{array}$ & $\begin{array}{l}\text { 't' value for } \\
\text { regression } \\
\text { coeff. }\end{array}$ & $\begin{array}{l}\text { Standarized } \\
\text { partial } \\
\text { regression } \\
\text { coeff. }\end{array}$ & $\begin{array}{c}\text { Coeff. of } \\
\text { determination }\end{array}$ \\
\hline Grain \% protein & $\begin{array}{c}\text { EP† } \\
\mathbf{B P} \\
\mathbf{K W T}\end{array}$ & 0.044 & $\begin{array}{r}0.819 \\
0.178 \\
-0.020\end{array}$ & $\begin{array}{l}39.24^{* *} \\
6.96^{* *} \\
-0.18\end{array}$ & $\begin{array}{r}0.885 \\
0.160 \\
-0.003\end{array}$ & 0.97 \\
\hline $\begin{array}{l}\text { Grain lysine } \\
\text { (\% of samples) }\end{array}$ & $\begin{array}{c}\text { EP } \\
\text { ELP } \\
\text { BP } \\
\text { BLP } \\
\text { KWT }\end{array}$ & -0.394 & $\begin{array}{l}0.018 \\
0.096 \\
0.010 \\
0.033 \\
0.003\end{array}$ & $\begin{array}{l}12.33^{* *} \\
5.16^{*} * \\
6.48^{* *} \\
2.79^{* *} \\
0.47\end{array}$ & $\begin{array}{l}0.826 \\
0.266 \\
0.369 \\
0.141 \\
0.023\end{array}$ & 0.85 \\
\hline
\end{tabular}

*** Indicates significance at the 0.05 and the 0.01 levels of probability, respectively.

$\dagger$ Abbreviations: $\mathbf{E}=$ endosperm, $\mathbf{B}=$ bran, $\mathbf{P}=$ percent protein, LP = lysine (\% of protein), KWT = 100-kernel wt. (g).

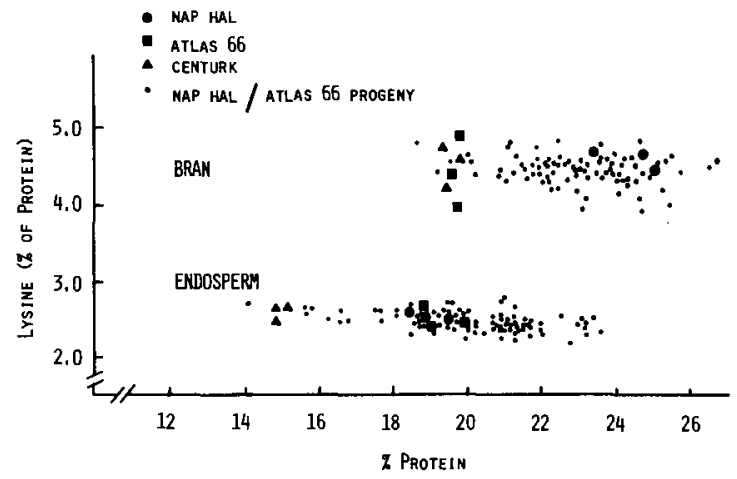

Fig. 1. Endosperm and bran protein and lysine percentages of parents and $F_{\bar{v}}$ progenies of the cross Nap Hal/Atlas 6.6

\section{RESULTS AND DISCUSSION}

The head rows of each cross were grown in separate areas within the head row nursery. The protein levels of Nap Hal and Centurk grain, endosperm, and bran samples were higher in the Nap Hal/Atlas 66 area (Table 1) than in the Nap Hal/Super $\mathrm{X}$ area (Table 2). Nap Hal was 4 percentages points higher in grain and endosperm protein concentration than Centurk in both nurseries and 5 percentage points higher in bran protein concentration. Direct comparisons between Nap Hal/Atlas 66 and Nap Hal/Super X progeny rows should not be made because of mean protein differences between the two areas of the nursery.

The Atlas 66 rows had high endosperm protein concentration while Nap $\mathrm{Hal}$ had both high endosperm and high bran protein concentration (Table 1, Fig. 1). These results were similar to those reported previously (12). Transgressive segregation existed both for high and low endosperm protein concentration among the Nap Hal/Atlas 66 progeny (Fig. 1). Lowprotein progeny lines had endosperm protein percentages similar to Centurk which were 3 to 5 percentage points lower than the endosperm protein percentages of either parent. Endosperm protein percentages of the very high progeny lines were 2 to 4 percentage points higher than either parent. These differences greatly exceeded the variation among the replicated parental rows. None of the progeny rows with low endosperm protein had bran protein percentages as high as Nap Hal. All of the progeny rows with very

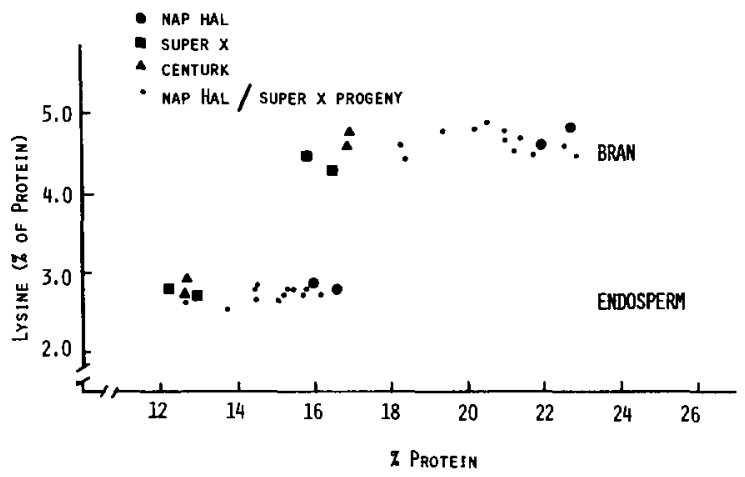

Fig. 2. Endosperm and bran protein and lysine percentages of parents and $F_{\downarrow}$ progenies of the cross Nap Hal/Super $X$.

high endosperm protein percentage were equal to Nap Hal in bran protein content.

These results suggest that $\mathrm{Nap} \mathrm{Hal}$ and Atlas 66 have different genes for high endosperm protein content whose effect is cumulative. The large range in endosperm protein concentration among the progeny rows indicated segregation of several genes. The results also suggest that $\mathrm{Nap} \mathrm{Hal}$ has genes for high bran protein concentration. Genes for high endosperm protein concentration may be required before the high bran protein concentration trait can be expressed.

The Nap Hal and Atlas 66 parent rows differed significantly for whole grain lysine concentrations but did not differ for endosperm lysine concentration ( $\mathrm{Ta}$ ble 1) even though in another 1973 Yuma nursery Nap Hal had significantly higher endosperm lysine content than Atlas 66 (12). In this study, the high grain lysine content of Nap Hal was associated with its high bran protein content. There was some variation among the progeny rows for endosperm and bran lysine content but it only slightly exceeded the variations among the replicated parental rows (Fig. 1).

The correlations between grain, endosperm, and bran protein and lysine concentrations among the Nap $\mathrm{Hal} /$ Atlas 66 progeny rows (Table 3) were similar to those reported previously for wheats from the USDA World Wheat Collection (12). The standard partial regression coefficients from the multiple regression analysis indicated that endosperm protein content was of primary importance in determining grain protein content (Table 4). Kernel weight did not affect 
grain protein content. Although the correlation of bran protein with grain lysine (\% of protein) was not significant, the standard partial regression coefficients from the multiple regression analyses (Table 4) indicated that bran protein concentration had more effect on grain lysine (\% of sample) than endosperm lysine (\% of protein). Endosperm lysine (\% of protein) had more effect on grain lysine (\% of sample) than bran protein content on wheats from the USDA World Wheat Collection (12). This difference between the two sets of data can be attributed to the segregation for bran protein content among the Nap Hal/Atlas 66 progeny. Kernel weight did not affect grain lysine content.

Nap Hal had higher grain, endosperm, and bran protein percentages than Centurk or Super X (Table 2). Endosperm and bran protein percentages of Nap Hal/Super X progeny rows were generally within the parental range (Fig. 2). Some of the progeny rows had endosperm protein percentages as large as those of Nap Hal but most were near the mid-parent level. These results suggested that some of the progeny rows inherited genes for high endosperm and bran protein content from Nap Hal. Some of these progeny rows also possessed the desirable agronomic characteristics of Super X. There was little variation among Nap Hal, Super $\mathrm{X}$, and their progeny rows for endosperm or bran lysine concentration (Table 2, Fig. 2).

Among wheats of the USDA World Wheat Collection, lysine (\% of protein) was negatively correlated with percent protein, i.e., as protein concentration increased lysine (\% of protein) decreased $(10,11)$. The results of both the Nap Hal/Atlas 66 and the Nap Hal/Super X crosses indicated that endosperm protein content may be increased without causing a concomitant decrease in lysine (\% of protein) since some highprotein progenies of both crosses had lysine values as high or higher than the low-protein progenies and low-protein cultivars, Centurk and Super X (Fig. 1 and 2). Another indication of the feasibility of improving endosperm protein content without adversely affecting endosperm protein quality was the positive, but non-significant correlation between endosperm protein and endosperm lysine for the progeny of Nap Hal Super X (Table 3).

Variation for grain protein content among the progeny rows of both crosses was due to variation both for endosperm and bran protein content. Because of the high lysine content of bran proteins, variation in bran protein content also influenced grain lysine content. Endosperm lysine content, because of its limited variability, had less effect on grain lysine content than endosperm and bran protein content in the crosses evaluated.

\section{REFERENCES}

1. AACC approved methods. 1962. American Association of Cereal Chemists. The Association. St. Paul, MN.

2. Farrand, E. A., and J. J. C. Hinton. 1974. Study of relationships between wheat protein contents of two U.K. varieties and derived flour protein contents at varying extraction rates. II. Studies by hand dissection of individual grains. Cereal Chem. 51:66-74.

3. Johnson, V. A., P. J. Mattern, J. W. Schmidt, and J. E. Stroike. 1972. Nutritional research on wheat at the University of Nebraska. p. 110-122. In Proc. 1st Int. Winter Wheat Conf., Ankara, Turkey. Nebraska Misc. Publ. 28.

4. - - - - - - - - , and - - - 1973. Genetic advances in wheat protein quality and composition. p. 547-556. In $\mathrm{E}$ R. Sears and L. M. S. Sears (eds.) Proc. Fourth Int. Wheat Genetics Sym., Missouri Agric. Exp. Stn., Columbia.

5. _-, J. W. Schmidt, and P. J. Mattern. 1971. Protein improvement in wheat. p. 166-172. In Proc. Third FAO/ Rockefeller Foundation Wheat Seminar. 29 Apr.-13 May 1970. Ankara, Turkey.

6. Mattern, P. J., J. W. Schmidt, and V. A. Johnson. 1970. Screening for high lysine content in wheat. Cereal Sci. Today. $15: 409-41$

7. McDermott, E. E., and J. Pace. 1960. Comparison of the amino acid composition of the protein in flour and endosperm from different types of wheat with particular reference to variation in lysine content. J. Sci. Food Agric. $11: 109-115$

8. Middleton, C. E., C. E. Bode, and B. B. Bayles. 1954. A comparison of the quality and quantity of protein in certain varieties of soft wheat. Agron. J. 46:500-502.

9. Steel, R. G. D., and J. H. Torrie. 1960. Principles and procedures of statistics. McGraw-Hill Book Co., Inc. New York.

10. Vogel, K. P., V. A. Johnson, and P. J. Mattern. 1973. Results of systematic analysis for protein and lysine composition of common wheats (Triticum aestivum L.) in the USDA World Wheat Collection. Nebraska Res. Bul. 258.

11. 1_-_, _-_, and - __. 1975. Reevaluation of selected wheats from the USDA World Wheat Collection for protein and lysine content. Nebraska Res. Bull. 272.

12. - - - - - , and -_- 1976. Protein and lysine content of grain, endosperm, and bran of wheats from the USDA World Wheat Collection. Crop Sci. 16:655-660.

13. - _ P. J. Mattern, and G. W. Lenser. 1976. A modified milling procedure for separating wheat bran and endosperm samples for protein and lysine analysis. Agron. J. 68:686690.

14. Watson, C. A., F. H. McNeal, M. A. Berg, and M. Menzel. 1966. Evaluating the quality potential of foreign wheats for breeding programs. Cereal Sci. Today. 11:326-27. 